BULLETIN Bulletin hispanique

HISPANIQUE Université Michel de Montaigne Bordeaux

118-2 | 2016

Varia

\title{
Degradación y elogio del ojo del culo
}

Motivos folclóricos del cancionero obsceno-escatológico popular

\section{Alberto del Campo Tejedor}

\section{OpenEdition}

\section{Journals}

Edición electrónica

URL: https://journals.openedition.org/bulletinhispanique/4656

DOI: 10.4000/bulletinhispanique.4656

ISSN: 1775-3821

Editor

Presses universitaires de Bordeaux

\section{Edición impresa}

Fecha de publicación: 15 diciembre 2016

Paginación: 693-728

ISBN: 979-10-300-0125-9

ISSN: 0007-4640

Referencia electrónica

Alberto del Campo Tejedor, «Degradación y elogio del ojo del culo», Bulletin hispanique [En línea],

118-2 | 2016, Publicado el 15 diciembre 2019, consultado el 21 septiembre 2021. URL: http://

journals.openedition.org/bulletinhispanique/4656 ; DOI: https://doi.org/10.4000/bulletinhispanique. 4656 


\title{
Degradación y elogio del ojo del culo. Motivos folclóricos del cancionero obsceno-escatológico popular
}

\author{
Alberto del Campo Tejedor \\ Universidad Pablo de Olavide - Sevilla, España
}

Dans le contexte festif de la culture comique populaire, les chansons scatologiques et obscènes sur l'anus présentent une ambivalence qui associe à l'exaltation du plaisir matériel la dégradation opérée par l'immonde : on y joue à jeter à terre le tabou et à mettre sous terre les sujets satirisés, non pour faire négativement affront mais pour que la joie par le terrestre et le charnel renaisse renouvelée : la nourriture, le sexe, la vie.

Mots-clés: chansons populaires, scatologie, obscénité, anus, plaisir, dégradation.

En el contexto festivo de la cultura cómica popular, el cancionero escatológico y obsceno sobre el ano presenta una ambivalencia, que sugiere a un mismo tiempo la exaltación del placer material y la degradación de lo inmundo: se juega a tirar por tierra el tabú y enterrar a los sujetos satirizados, pero no como mera afrenta negativa, sino para que renazca renovada la alegría por lo terrenal y carnal; la comida, el sexo, la vida.

Palabras claves: canción popular, escatología, obscenidad, ano, placer, degradación.

In the festive context of comical popular culture, scatological and obscene songs about the anus present an ambivalence, which suggests at the same time the exaltation of worldly pleasure and the degradation by the filth. The play throws to earth the taboo and buries the satirized subjects, not as mere negative affront, but in order that the happiness for the carnal, the earthly -food, sex, life- will be reborn, renewed.

Keywords: popular song, scatology, obscenity, ass, pleasure, degradation.

\section{INTRODUCCIÓN}

Si la literatura obscena popular ha interesado a la academia (tanto a la filología, como a la historia y a la antropología social), la escatológica ha sido considerada mayoritariamente un divertimento de nula relevancia, como si ciertas prácticas, 
por referirse a cuestiones consideradas inmundas, tuvieran que ser ocultadas, especialmente bajo ciertas perspectivas folclorísticas y románticas donde el bucólico Volksgeist resonaría más fuerte que la carcajada licenciosa. El culo, como los demás orificios corporales, es un órgano ambivalente en las culturas populares, como destacara Mijail Bajtin ${ }^{1}$ en su estudio sobre la obra de Rabelais. En su función fisiológica de excreción, el ano es el basurero del cuerpo, el lugar de expulsión de desechos transmisores de enfermedades y hedores. El proceso civilizatorio occidental centró en el control del cuerpo uno de sus esfuerzos educadores, confinando ciertos actos al ámbito de lo privado, y borrando la ambivalencia que los excrementos y las ventosidades han suscitado durante siglos. Y es que la mierda o el pedo, como el resto de excreciones corporales -el sudor, las lágrimas, la sangre, la orina- no juegan en las culturas populares un papel inequívocamente negativo. En el contexto de la fiesta -liberadora, igualitaria y antirreglamentaria- ve Bajtin el lugar donde se desarrolla la cultura cómica popular, basada en la inversión del orden y muy especialmente de la seria y jerárquica cotidianeidad. En el tiempo extraordinario de la fiesta rige un tipo de lenguaje que exalta el placer, la alegría, la risa. Pero esta no deriva de una simple apología de lo carnal -tanto en su vertiente sexual como alimentaria-, sino que el humor carnavalesco es consecuencia de una lógica ambivalente que deforma, exagera, hipertrofia lo material y corporal, algo que Bajtin bautizó como realismo grotesco ${ }^{2}$.

Los orificios corporales son ambivalentes, porque por ellos el cuerpo se abre al mundo, y ambos -cuerpo y mundo- encierran en sí tanto lo bajo como lo alto, lo inmundo como lo sublime. Los ojos esconden la cándida mirada pero también las legańas o la salada lágrima, como la nariz es protuberancia donde se alojan los mocos; el oído permite el susurro amoroso pero de él emana cera entre los pelos; la boca es un órgano más complejo -fuente de la palabra, el canto, el suspiro, el beso y el gusto- pero su formidable funcionalidad y sensibilidad no extirpa su lado negativo: el escupitajo, la podredumbre de la dentadura en la vejez, el aliento fétido. En el simbolismo corporal, en concordancia con el topográfico de la tierra y el cielo, la parte superior del cuerpo, y muy especialmente el rostro, simboliza lo alto, espiritual y noble, pero el realismo grotesco juega precisamente a invertir el orden, recordándonos la faz sucia y degradante. La parte inferior del cuerpo pertenece a lo inmundo, lo bajo, pero sus órganos -el vientre, el ano, el falo, la vagina- no son solo fuente de excreciones (ventosidades, excrementos, semen, sangre menstrual, flujo vaginal) sino también del placer, la sexualidad, el nacimiento, la vida. La vagina o el ano pertenecen a lo impuro, y por lo tanto son objeto de múltiples tabúes; pero también conforman lugares eróticos, de ensoñación, y aun están relacionados con la fertilidad, el crecimiento, la abundancia. 
Enfatizando lo sucio, hediondo, putrefacto, corrompido y viejo, el realismo grotesco degrada, pero no lo hace como la sátira moderna -en un sentido meramente negativo-, sino precisamente desatando la carcajada, liberándonos del tabú, reconociendo la doble faz de cualquier realidad. Al tirar por tierra, es decir, al rebajar la faz alta, espiritual, noble, el realismo grotesco iguala e instaura un efímero marco en que puede representarse la utopía, pues nos recuerda que la idealización, el orden o la norma no son inherentes a las cosas y las personas, sino un proceso esencialmente ideológico y político. La risa deriva en gran medida de la mezcla de lo bajo y lo alto, lo profano y lo sagrado, lo ínfimo y lo sublime, y muy especialmente de la incertidumbre de qué polo predominará; de ahí que la literatura obsceno-escatológica sea eminentemente lúdica y ambigua. Aún hoy, en contextos de fiesta popular, irrumpen canciones que exaltan el placer, reivindican lo corpóreo, pregonan a los cuatro vientos las bondades de la carne, incluso de los actos fisiológicos más bajos (ventosear y defecar), liberándonos así de la culpa por el pecado y las convenciones del decoro. Pero también, incluso muchas veces simultáneamente, estas coplas enfatizan lo sucio e inmundo: el repulsivo pedo de la vieja, la deformidad monstruosa de la embarazada, el insoportable hedor de las heces, depositadas frente a la puerta de la amada, o la suegra.

Si los órganos del placer, la sexualidad y la vida son también los de la sangre, la orina y los excrementos, no extrańa encontrar en la literatura obscenoescatológica en torno al culo una ambivalencia que forma parte de una lógica cósmica típica de las culturas agroganaderas, según la cual el mundo se mueve por la incesante lucha de contrarios: cielo y tierra, hombre y mujer, invierno y verano, vida y muerte. El culo es el equivalente corporal de la tierra, y se opone a la cabeza como la tierra es la antítesis del cielo. Pero con las mordaces coplas escatológicas no solo se tira por tierra al motejado, sino que se le entierra, se le mata simbólicamente para permitir la regeneración, el renacimiento, según la lógica de un tiempo cíclico que Mijail Bajtin, Mircea Eliade y otros muchos autores han descubierto como sintomática de las culturas campesinas, vinculadas a los ciclos de la naturaleza. La tierra, como la mierda, es un sustrato fértil, de la misma manera que el pedo, aunque pestilente, es síntoma de buen comer y de salud, como atestiguan los refranes que sentencian "come mucho y caga fuerte, y no temas a la muerte ${ }^{3}$. Tras la degradación obsceno-escatológica, el realismo grotesco cava la tumba corporal, pero con ello, más que la negación y la disolución, sugiere un nuevo renacimiento, ya que lo corporal-terrenal, lo bajo y sucio, es símbolo de «lo inferior productivo, donde se efectúa precisamente la concepción y el renacimiento, donde todo crece profusamente» ${ }^{4}$.

La desvalorización de este tipo de literatura por parte de ciertas capas cultas, no es independiente de la incomprensión de su sentido profundo. La

3. También Góngora afirmaba: «Buena orina y buen color / y tres higas al doctor» (L. de Góngora, Obras completas, recopilación, prólogo y notas de Juan Mille y Giménez, Isabel Mille y Giménez, Madrid, Aguilar, 1972, p. 298).

4. Bajtin op. cit., p. 26. 
mayoría de muestras que aquí estudiamos están vigentes y muy extendidas por diferentes pueblos y localidades, si bien los cancioneros publicados casi nunca las recogieron o, si lo hicieron, las pulieron hasta extirpar toda palabra malsonante. Así, por poner un solo ejemplo, Melchor de Palau incluyó en sus Cantares populares y literarios (1900) un apartado de versos "pícaro-burlescos»" pero del casi medio millar de composiciones de este tipo que recopiló, ni una sola es escatológica. El propio Palau reconocía:

Varia, alegre, satírica, burlona, doblemente intencionada y no siempre tan casta como la supone García Gutiérrez ${ }^{6}$ es la musa popular, lo cual se demuestra en la parte última de la colección que lleva por título Cantares joco-burlescos ${ }^{7}$, en la que se ha debido suprimir no poco de lo recogido por esos andurriales. ${ }^{8}$

Para el antropólogo social ese «no poco» es en realidad «mucho», pues permite comprender una faceta del ser humano, no por premeditadamente discriminada por los estudiosos, menos significativa.

\section{EROTISMO Y ESCARNIO EN EL CULO FEMENINO:}

TODAS LAS MUJERES TIENEN...

Culos femeninos y masculinos tienen un muy dispar tratamiento en el cancionero popular, tanto en lo que respecta al erotismo y la sexualidad, como en lo referente a lo escatológico. La fiesta destapa lo habitualmente oculto, aunque sea mediante la imaginación y la mención verbal, y así algunas tonadas de baile están tan arraigadas que se pueden escuchar por toda la geografía, desde Andalucía, hasta Asturias:

$$
\begin{aligned}
& \text { Anda, nińa, y componte, } \\
& \text { vamos al baile } \\
& \text { con la camisa rota } \\
& \text { y el culo al aire? }
\end{aligned}
$$

Las nalgas femeninas son, para el hombre, oteros de ensueño, un valle erótico, asociado no solo a la belleza, sino a la sexualidad. Ya lo dice el refrán: "Al papel y a la mujer, hasta el culo le has de ver», y como ańade pícaramente

5. M. de Palau, Cantares populares y literarios, Barcelona, Montaner y Simón, 1900, pp. 263286.

6. Antonio García Gutiérrez, que en su discurso de entrada a la Real Academia Española había tratado sobre la poesía popular castellana.

7. El apartado acabaría titulándose, empero, «pícaro-burlescos».

8. Palau, op.cit., p. 17.

9. Copla muy divulgada desde Cantabria (F. Gomarín, Cancionero secreto de Cantabria, Santander, Universidad de Cantabria, 1989, p. 90) hasta Andalucía. En Bailén (Jaén) se cantaba: «La seńorita x / ha entrado en el baile / con la camisa rota / y el culo al aire...». Se han recogido otras versiones similares, por ejemplo en Tolbaños de Arriba, Burgos (M. Manzano Alonso, Cancionero Popular de Burgos. Tomo II: Tonadas de baile y danza, Burgos, Diputación Provincial de Burgos, 2001, p. 245). 
uno de nuestros informantes de la Alpujarra: «y si puedes maniobrar, no lo olvides de catar». El ingenio popular lo ha expresado muchas veces con sencilla sensualidad, como en esta copla que cantan los buenos flamencos en Priego (Jaén):

Gitanilla, menea ese culo, ese culo, que te quiero ver bailar, que está aquí tu gitanillo que te quiere de verdad. ${ }^{10}$

Aunque el hombre ha querido muchas veces salpimentar el erotismo con una pizca más de guasa:
Han ido a ver las nalgas de las mozas de pueblo porque las de capital no tienen consuelo. ${ }^{11}$
Cásate y tendrás mujer y le tocarás el culo y a eso de los quince días como si tocas el tuyo. ${ }^{12}$

La voluptuosidad del trasero suscita imágenes que juegan con el doble sentido que tiene la carne; de ahí que el culo sea metafóricamente devorado, lamido:

$$
\begin{aligned}
& \text { Vaya culo, qué hermosura, } \\
& \text { vaya nalgas, qué obsesión, } \\
& \text { no sigo con otras partes } \\
& \text { que me dan indigestión. }{ }^{13} \\
& \text { Si el culo de la Pepa } \\
& \text { fuera de azúcar } \\
& \text { estaría su novio } \\
& \text { chupa que chupa. }{ }^{14} \\
& \text { La sobrina del cura } \\
& \text { de Villarquite } \\
& \text { tiene el culo redondo } \\
& \text { como un confite. }
\end{aligned}
$$

Pero también los orificios femeninos devoran la carne del macho, y así los jóvenes de Villanueva de la Vera (Cáceres) cantan:

10. E. Alcalá Ortiz, Cancionero popular de Priego: poesía cordobesa de cante y baile, vol. IV, Priego de Córdoba, Ayuntamiento de Priego de Córdoba, 1991, p. 678.

11. Castilla (G. Díez Barrio, Coplas y cantares populares, Valladolid, Castilla ediciones, 1995: 67).

12. Se canta o dice en muchos pueblos de Castilla, con diversas variantes (M. Urbano, Sal gorda. Cantares picantes del folklore español, Madrid, Hiperión, 1999, p. 209).

13. Candeal, Rabeladas «a lo pesao», Valladolid, Editorial Maxtor, 2007, p. 69.

14. Urbano op.cit., p. 139.

15. Valle de Campoo, Cantabria (Gomarín, op. cit., 93). 
El culo le dijo al chocho: eres un mal compañero, que te comes el chorizo y a mí me dejas los huevos.

Y los de Beas de Segura (Jaén):

Dame ya la sartenilla la que tienes junto al culo, para freír unos huevos y de longaniza, un tarugo.

Por su parte, la mujer ha respondido a semejante interés con coplas igualmente humorísticas, como las que pueden recogerse en algunos pueblos de Zamora, como Muelas de los Caballeros.

\author{
Si quieres saber quién soy, \\ y de qué pelaje vengo, \\ levántame el faldón \\ y verás qué culo tengo. \\ Por una peseta \\ enseño una teta. \\ Por dos, las dos. \\ Por tres, el culo. \\ Y por un duro, \\ el rascataplán peludo.
}

El contexto típico de este tipo de coplas, en boca de mujeres, eran hasta hace unas décadas los lavaderos u otros lugares de comadreo femenino, donde era diversión fustigar con pullas y abucheos a cualquier hombre que osare pasar cerca. Pero son los mozos, los que han entonado más frecuentemente coplas eróticas y obscenas en alusión a los orificios femeninos:

$$
\begin{aligned}
& \text { Todas las mujeres tienen } \\
& \text { hacia el culo un celemín, } \\
& \text { también los hombres tenemos } \\
& \text { rasero para medir. }{ }^{16} \\
& \text { Desde el culo al ombligo } \\
& \text { de las mujeres } \\
& \text { hay un santo que llaman } \\
& \text { Domingo Pérez. }{ }^{17}
\end{aligned}
$$

Orificios tan cercanos han generado irremediablemente abundante material obsceno-escatológico:

$$
\begin{aligned}
& \text { La mujer del herrero } \\
& \text { dicen que tiene } \\
& \text { por delante la fragua }
\end{aligned}
$$

16. Segovia (L. D. Delgado, «Las pullas», Revista de Folklore, tomo 6, nº 62, 1986); Valle de Valderredible, Cantabria (Gomarín, op. cit,. p. 69).

17. Urbano op. cit. 107. 
y atrás el fuelle.

De las dos cosas

es mejor la que quema

que la que sopla. ${ }^{18}$

El ano, la vagina, el ombligo son todos ellos lugares ambivalentes; pertenecen a lo inferior, pero se vinculan a la fertilidad, la abundancia, el sexo:

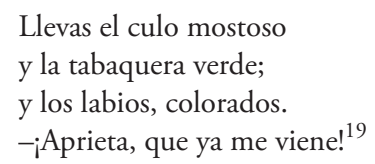

Como cavidad, el culo tiene todas las connotaciones de pasividad, inferioridad y sumisión, según arcaica concepción que, a partir del actomodelo de penetración y como consecuencia del isomorfismo entre relación sexual y relación social, dicotomiza la sexualidad en dos polos contrarios pero complementarios: masculino y femenino, activo y pasivo, dominador y dominado ${ }^{20}$. Los mozos de Cádiar, en la Alpujarra granadina, cantan remedando la voz de alguna muchacha:

$$
\begin{aligned}
& \text { Si me clavas el puñal, } \\
& \text { no lo claves en el pecho; } \\
& \text { clávamelo en el culo, } \\
& \text { que tengo el gujero hecho. }
\end{aligned}
$$

No menos conocida es esta vieja canción de quintos:

$$
\begin{aligned}
& \text { Si quieres que te la meta } \\
& \text { me tienes que dar un duro, } \\
& \text { que cuesta mucho trabajo } \\
& \text { el meterla por el culo. }{ }^{22}
\end{aligned}
$$

Sin duda, la mayoría de coplas obscenas y escatológicas son cantadas y pensadas desde el universo de valores y prácticas masculinas, algo que los estudiosos del folclore y la literatura oral -Lombardi Satriani ${ }^{23}$, Margit Frenk ${ }^{24}$,

18. La Mancha (A. Carretero, Pisto Manxego. El arte del bien comer y mejor cagar, edición del autor, 2006, p. 73).

19. Urbano, op. cit., p. 210.

20. M. Foucault, M., 1984, Historia de la sexualidad, vol. II. El uso de los placeres, México, Siglo XXI, 1994, p. 198.

21. La misma versión la recoge Urbano (op.cit., p. 139). Otras: «Si me quieres tirar flechas / no me las tires al pecho, / me las tiras en el culo / que el agujero ya está hecho» (Candeal, op.cit, p. 54).

22. Aunque otras versiones aluden a la penetración vaginal: «Si quieres que te la meta / me tienes que dar mil duros / que cuesta mucho trabajo / hacer un crío desnudo» (Zamora); «Si quieres que te la meta, / me tienes que dar un duro, / que cuesta mucho trabajo, / hacer un niño peludo» (Bogorra, Albacete).

23. L. M. Lombardi Satriani, Apropiación y destrucción de la cultura de las clases subalternas, México, Nueva Imagen, 1978, p. 32.

24. M. Frenk, Poesia popular hispánica, México, Fondo de Cultura Económica, 2006, p. 21. 
Del Campo ${ }^{25}$ - hemos constatado reiteradas veces. Cuando la testosterona se alía con la misoginia, cantan los mozos en infinidad de pueblos repartidos por toda la Península:

$$
\begin{aligned}
& \text { No me jodas en el suelo } \\
& \text { que no soy ninguna perra, } \\
& \text { que por cada balanceo } \\
& \text { me echas en el culo tierra. }{ }^{26} \\
& \text { En vez del sesenta y nueve } \\
& \text { haremos [el] setenta y uno, } \\
& \text { que es como el sesenta y nueve } \\
& \text { con dos dedos en el culo. }{ }^{27}
\end{aligned}
$$

Son centenares las coplas calenturientas que apelan al coito, como acto violento, paradigma de la dominación masculina sobre la mujer sometida, muy al gusto de lo que los mozos exhiben en sus muestras de hombría en esa edad en que aún no son considerados todavía hombre, pero se empeñan en marcar distancias con respecto a los niños, sus hermanas y madres. Por eso, más que el coito vaginal, el anal es fuente de exhibición de poder y dominio, como es simbólico de la relación carnal desprovista de todo ánimo de procreación, ni consideración sentimental hacia la pareja. No faltan en estos contextos de fiesta y borracheras de jóvenes las coplas que mezclan el coito con los excrementos, en una singular y ambivalente mezcla de placer y suciedad, típica del realismo grotesco:

$$
\begin{aligned}
& \text { Decía la tía Ciruela: } \\
& \text {-Sácamela que me cago, } \\
& \text { que no me cabe en el cuerpo } \\
& \text { ese pingajo tan largo. }{ }^{28}
\end{aligned}
$$

Es la típica hipertrofia, que deforma y estira hacia dos polos antitéticos lo que se considera ambivalente: el sexo, como el propio alumbramiento, a la vez generador de vida, de placer, pero también vinculado a lo sucio, la menstruación, la placenta, la sangre. No extrańa, por lo tanto, que el parto y el embarazo no sea tanto un tópico cantado con lirismo, sino que sugiera por un lado la ambigüedad de todo lo que transita por los orificios corporales, y por otro la propia deformación del cuerpo femenino, alterado grotescamente:

$$
\begin{aligned}
& \text { ¡Válgame Dios, qué trabajos } \\
& \text { para la mujer preńada! } \\
& \text { cuando va a cagar, se mea, } \\
& \text { cuando va a mear, se caga. }{ }^{29}
\end{aligned}
$$

25. A. del Campo Tejedor, Trovadores de Repente. Una etnografía de la tradición burlesca en los improvisadores de la Alpujarra, Salamanca: Miletnio, Diputación de Salamanca, 2006.

26. Díez Barrio op.cit., p.68. Una versión similar cantan los jóvenes y no tan jóvenes en Navaleno, Soria: «No me jodas en el suelo / como si fuera una perra / que con esos cojonazos / me llenas el coño [de] tierra», copla extendidísima por toda la península.

27. Soria.

28. Urbano, op. cit., p. 135.

29. Valle de Polaciones, Cantabria (Gomarín, op.cit., p. 70). 
En las culturas agroganaderas, apegadas a los ritmos de la naturaleza, lo obsceno no ha sido más que la versión festiva y grotesca de una concepción que valoraba la sexualidad y la procreación apotropaicamente, sin perder de vista una cosmología según la cual la vida y la muerte se suceden naturalmente. La iniciativa amorosa y sexual reside en el hombre, por supuesto, y las relaciones preconyugales son censuradas en mayor medida que en el varón. No podía ser de otra manera en el seno de un cristianismo ascético que desde antiguo pinta el pecado y la tentación de la carne con cuerpo femenino. Pero habrá que recodar con Bajtin ${ }^{30}$, de nuevo, que lo ínfimo es para las culturas populares a la vez rebajador y regenerador, de ahí el lugar ambivalente de la mujer: «La mujer rebaja, relaciona a la tierra, corporaliza, da la muerte; pero es antes que nada el principio de la vida, el vientre. Tal es la base ambivalente de la imagen de la mujer en la tradición cómica popular ${ }^{31}$. Tal vez por eso haya sido tan frecuente encontrar en la canción popular no solo una visión ambigua y desconcertante del amor y la sexualidad, sino la proliferación de contrafacta disparatados que suponen la visión cómica, carnal y deformada de la lírica amorosa. Así, en muchos pueblos se cantan piropos que comienzan con «en el mar se crían peces»:

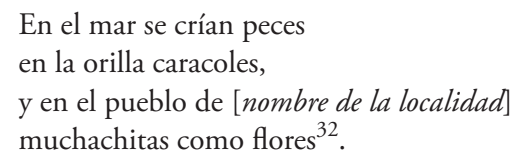

Estas pueden aderezarse de picardía para, de repente o habiéndose compuesto previamente, sorprender a la concurrencia:

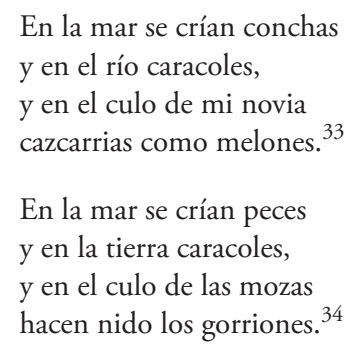

La tradición de parejas de coplas amorosas y sus parodias chuscas es antiquísima. La encontramos ya en el Vocabulario de refranes y frases proverbiales (1627) de Correas:

$$
\begin{aligned}
& \text { ¡Ay de mí, que la miré, } \\
& \text { para vivir lastimado, } \\
& \text { para llorar y gemir } \\
& \text { cosas del tiempo pasado! }
\end{aligned}
$$

30. Op.cit., p. 215.

31. Idem.

32. Las versiones cambian; así se sustituye también «pueblo» por «calle», o «flores» por «soles».

33. Urbano, op. cit., p. 140.

34. Asturias (Suárez/Ornosa, op.cit., p. 74). 
¡Ay de mí, que la miré!

¿Y adónde la besaré?

-En el ojo del trasé. ${ }^{35}$

Por la misma época, por cierto, se recogían en el Cancionero de Jacinto López (1620), canciones que jugaban precisamente a mezclar lo obsceno y lo escatológico, deformando grotescamente esos órganos ambivalentes y multifuncionales:

\author{
En esta calle mora \\ una moça caripapuda \\ que con las tetas barre la casa \\ y echa pedos a la basura. ${ }^{36}$
}

\title{
LA AFRENTA SATÍRICA: AMARILLO CANARIO TIENES EL CULO...
}

Frente a la exaltación erótica o sexual del culo femenino, los jóvenes se han acordado de él también para las pullas y matracas frecuentes en las rondas de mozos, especialmente con motivo de las fiestas de quintos, aunque también, aún hoy, en ciertos juegos de pique y escarnio cuando los jóvenes de ambos sexos celebran en estrecho contacto:

\author{
Te pusiste a escoger \\ en un canasto de peras \\ y luego fuiste a dar \\ con el culo en la gotera. ${ }^{37}$ \\ Amarillo canario \\ tienes el culo; \\ aunque no te lo he visto, \\ me lo figuro. ${ }^{38}$ \\ Las muchachas de Cabrita \\ tienen el culo pelao \\ de subirse a la higuera \\ y bajarse al arrastrao. ${ }^{39}$
}

Más ambigua es esta copla, propicia para que las suegras la canten a nueras demasiado coquetas:
Dice la suegra a la nuera:
-Bien te peinas, bien te lavas;
no habrá miedo que te críen
en el culo telarañas. ${ }^{40}$

35. G. Correas, Vocabulario de refranes y frases proverbiales (1627), edición de Louis Combet, revisada por Robert Jammes y Maïte Mir-Andreu, Madrid, Editorial Castalia, 2000, p. 113; Frenk op.cit., p. 1399; NC 1953.

36. Frenk, op.cit., p. 1401.

37. Albolote (Granada).

38. Urbano, op. cit., p. 139.

39. Idem.

40. J. M. Fraile (ed. crit.), «Un muestreo en la Poesía Tradicional de la Mancha Baja», Zahora. 
Si se critica el excesivo aseo, hay muchas otras canciones que satirizan a la guarra. A diferencia de la apología de lo sucio y la defensa de las cochinadas como irreverencias festivas propias de mozos, la mierda es en la mujer estigma devaluador, como la sangre, que remite a lo impuro, lo inmundo:

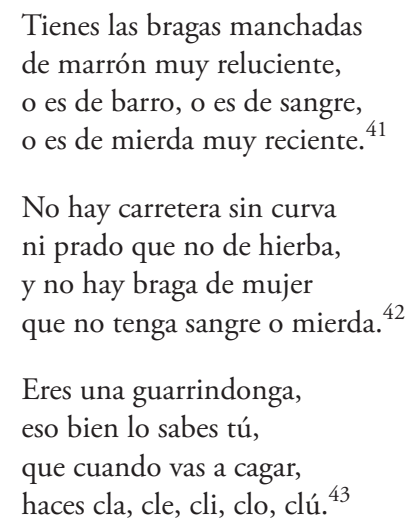

Son el contrapunto a las coplas que resaltan la limpieza y candor femenino ${ }^{44}$. Pelos y almorranas completan la visión grotesca del culo femenino:

Tienes granos en el culo
y en el ombligo también;
tienes mal los dos agujeros
y el otro ya veré. ${ }^{45}$
Dices que tienes, que tienes.
¡qué coño vas a tener:
cuatro pelos en el culo,
igual que cualquier mujer! ${ }^{46}$

Como principal órgano de evacuación, el culo es la cloaca del cuerpo.
Las muchachas de Cabrita
tienen el culo podrio
de comer panochas tiernas
y beber agua del río. ${ }^{47}$

Revista de Tradiciones Populares, 33, 1993, p. 151.

41. Candeal, op. cit., p. 57.

42. Valle de Polaciones, Cantabria (Gomarín, op. cit., p. 62).

43. Zaragoza. En otras versiones (Candeal, op.cit. p. 34) el cla, cle, cli, clo, clu responde al sonido del orinar.

44. Del tipo «Límpiate con mi pañuelo, / yo lo lavaré mañana, / que la limpieza del cuerpo / es el espejo del alma» (Soria).

45. Candeal, op. cit., p. 56.

46. Hay versiones menos escatológicas, como esta de Castrobarto, Burgos: «Dices que tienes, que tienes / ¡qué coño vas a tener!: / ajos, como la cigüeña, / y pico $p a^{\prime}$ componer» (Manzano, op. cit., p. 290).

47. Urbano, op.cit., p. 137. 
Sin embargo, dado que la mujer es la dadora de vida, el campesinado ha enjuiciado ambivalentemente lo que sale del ano, en el fondo estiércol, inmundo pero que abona las plantas y propicia la fertilidad:

$$
\begin{aligned}
& \text { Para sembrar remolacha } \\
& \text { no hay terreno como el culo, } \\
& \text { que tiene el abono cerca } \\
& \text { y el regadío es seguro. }{ }^{48}
\end{aligned}
$$

Son coplas que, en el fondo, remiten a la tradición poética que asemeja el cortejo y aun el sexo, al trabajo en el huerto o la viña, según la arcaica ligazón tierra-mujer-agricultura-fecundidad-prosperidad-vida.

El cuerpo de una mujer es lo mismo que una huerta: tiene la noria en el medio y el perejil a la puerta. ${ }^{49}$

La conexión simbólica entre la tierra y el cuerpo femenino explica coplas que en apariencia resultan incomprensibles:

$$
\begin{aligned}
& \text { A una nińa muy bonita } \\
& \text { le operaron en el culo, } \\
& \text { le sacaron cuatro nueces } \\
& \text { y un melocotón maduro. }
\end{aligned}
$$

Es la ambivalencia del cuerpo femenino y, muy especialmente, de sus agujeros, motivo de calentura para el hombre, pero también órganos de evacuación ${ }^{51}$. Frente a la blancura virginal, la negrura del ano ha dado para no pocas coplas guasonas, como las que se cantan en Navaleno (Soria) y en muchos otros pueblos ${ }^{52}$, y que asocian, de nuevo, la obscenidad a la agricultura.

48. Díez Barrio, op.cit., p.69. En cada lugar, claro está, se siembra algo diferente: «Para sembrar zanahorias / el mejor roal el culo, / que está el regaero cerca / y el basurero seguro» (Urbano, op.cit., p. 140); «Si quieres patatas frescas / siémbralas dentro del culo, / tendrán el abono cerca / y el regadío seguro» (Suárez/Ornosa, op.cit., p. 127). "Del culo de las mujeres / se puede hacer una huerta, / tienen el abono al pie / y el agua a la misma puerta» (Gomarín, op.cit., p. 41).

49. Castrocalbón, León (M. Manzano, Cancionero leonés, vol. I, tomo II: Tonadas de baile, León, Diputación Provincial de León, 1993, p. 73). En el valle de Polaciones (Cantabria) se canta una versión similar: «El cuerpo de una mujer / es parecido a una huerta: / tiene el regadero al pie / y el perejil a la huerta» (Gomarín, op.cit., p. 55). Y también: "Desde que te fuiste, Pedro, / el huerto no se ha regado, / la mala hierba ha crecido, / el perejil se ha secado» (Gomarín, op.cit., p. 69). En Andalucía, cualquier aficionado al flamenco reconoce coplas que aluden a esa misma ligazón simbólica: «Por entrarme en la huerta / de otro labrador, / otro se entró en la mía / tomó posesión».

50. Urbano op.cit., p. 140.

51. Esta ambivalencia es aún más frecuente en el caso de la vagina: «Por muy repulida, moza, / por repulida que seas, / no dejarás de mojarte / los pelillos cuando meas»; «Si me das el con que meas / yo te daré el con que orino, / y entre los dos formaremos / un pueblo de dos vecinos» (León).

52. Las hemos escuchado en diferentes localidades de Zaragoza, Logroño, Soria, Burgos o Zamora. 


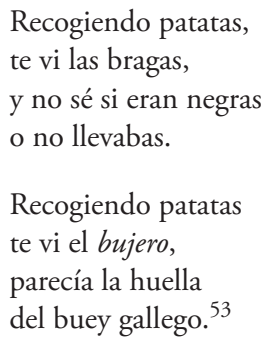

Además de la negrura y la suciedad, la gordura es motivo típico del realismo grotesco, ya que supone una deformación del cuerpo como consecuencia del comer, el pecado de la gula, y en general la hipertrofia de los placeres mundanos. Las Gracias y desgracias del ojo del culo de Quevedo van dedicadas, precisamente, a una tal «Juana Montón ${ }^{54}$ de carne, mujer gorda por arrobas» ${ }^{55}$, en un claro guiño al realismo grotesco. En muchos lugares, las conocidas coplas que dan comienzo con «las mocitas de mi pueblo», pintan a estas como brutas y groseras:
Las mocitas de mi pueblo son muy robustas doncellas, con el culo parten nueces sentándose sobre ellas. ${ }^{56}$

Frecuentemente la gordura se alía con la suciedad para aumentar el efecto grotesco:

$$
\begin{aligned}
& \text { No te cases con mujer } \\
& \text { de culo gordo, } \\
& \text { que cuando se tira un pedo, } \\
& \text { te deja sordo. } \\
& \text { A la gorda, la gorda, } \\
& \text { le pica el culo } \\
& \text { y se rasca, se rasca, } \\
& \text { con un tarugo. }
\end{aligned}
$$

De diferente calado son las coplas que tratan el culo del hombre, aunque no menos ambivalentes, ya que si los actos fisiológicos anales pueden ser exaltados carnavalescamente como los placeres más mundanos de todos, el ano es un lugar por donde puede colarse el miedo a que se destape la femineidad del macho.

53. Hay muchas otras, difundidas por toda la Península: «Arrancando garbanzos / te he visto el culo, / no he visto chimenea / que eche tanto humo. // Recogiendo tomates / te he visto el culo / y si no te lo he visto / me lo figuro".

54. O Juana Mucha, según otras ediciones.

55. F. de Quevedo, Prosa festiva completa, edición de Celsa Carmen García-Valdés, Madrid, Cátedra, 1993, p. 356.

56. Candeal, op. cit., p. 41.

57. Urbano, op.cit., p. 129. Más ambigua es la siguiente: «Aunque seas de Albolote, / yo con el cante de aturruyo, / haz el favor de decirme, / los pliegues que tiene un culo (Albolote, Granada). 


\section{El CUlO MASCUlino: NO TE PONGAS POR DELANTE \\ O ÉCHATE LA MANO ATRÁS...}

Margit Frenk ${ }^{58}$ recoge en su recopilación de lírica popular hispánica entre los siglos XV y XVII, algunas coplas de indudable sabor popular y carnavalero:

$$
\begin{aligned}
& \text { Salió el so[l] en maio } \\
& \text { y diome en el rabo; } \\
& \text { y sopla: } \\
& \text { ¿no es buena copla? } \\
& \text { Salió el sol en junio } \\
& \text { y diome en el culo; } \\
& \text { y sopla: } \\
& \text { ¿no es mejor copla? }
\end{aligned}
$$

Muchas de las cancioncillas picantes sobre el culo masculino muestran la misma hipertrofia degradante de lo material y carnal, que encontramos en las que cantan las inmundicias del culo femenino:

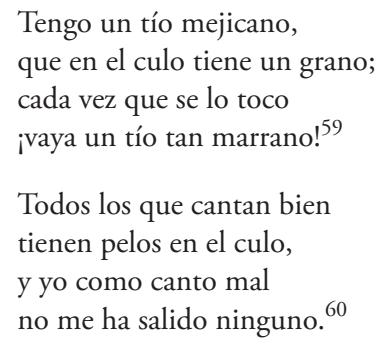

Pero hay una diferencia sustancial: el mozo, necesitado de mostrar su displicencia y su emancipación con lo considerado femenino (lo limpio, el espacio doméstico, lo recatado), exalta no solo lo desaliñado (de ahí la fobia a la ducha, al peine y a la muda, que solo las madres tratan de que no caigan en olvido), sino explícitamente lo sucio, lo bajo. Es lo que han observado los antropólogos ${ }^{61}$ especialmente en esa ruptura iniciática con el mundo femenino que supone la quinta, punto de inflexión de la mocedad antes de hacerse un hombre, y donde las canciones que ensalzan lo macho y degradan lo hembra son un componente esencial. En ese contexto, están arraigadísimas las coplas de mozos en las que se exhibe cómicamente lo que en el caso de la mujer es afrenta satírica:

58. Op.cit., p. 1397; NC 1952.

59. Urbano, op. cit., p. 140.

60. Valle de Campoo, Cantabria (Gomarín, op. cit., p.77).

61. P. A. Cantero, «Hombrear. Modos de aprender a ser hombre», Hombres. La construcción cultural de las masculinidades, Valcuende del Río y Blanco López (eds.), Madrid: Talasa, 2003, pp. 53-65. 
Estoy feliz, estoy contento con los pelos de mi culo, ayer yo me los conté y no me faltaba ninguno. ${ }^{62}$

Uno de los motivos más frecuentes en el cancionero del culo masculino es el de la sodomización, utilizada como amenaza, en tono de broma, tal y como hacen por ejemplo los troveros de la Alpujarra y el Poniente almeriense, especialmente en aquellos combates priápicos en que se hace alarde de los atributos de uno, mientras se degrada al rival, motejándole de burra, nena, bujarro.

\author{
Esta frase te la anulo \\ al no conocer mi clavo. \\ Tú no te pongas tan chulo. \\ ¡Si conocieras mi rabo, \\ tú no pondrías el culo! \\ Ahora en este mismo instante, \\ Barranco no te decoro. \\ No te pongas por delante: \\ ¡Tengo los huevos de toro \\ y la picha de elefante! ${ }^{63}$
}

El dar por culo es en el contexto de masculinidad tradicional, metáfora de poder y sumisión, de ahí que cuando se expresa como broma en las canciones picantes, se aluda por igual al contexto de igualdad y camaradería donde estas licencias verbales son posibles, y al poderío del que habría de hacer ostentación el hombre hecho y derecho. El rico, el poderoso, el conde, el militar es el que sodomiza en las coplas populares:

$$
\begin{aligned}
& \text { Súbete las bragas, moza } \\
& \text { que vienen los melitares, } \\
& \text { a mí me darán pol culo } \\
& \text { y a ti te sacan cantares. }{ }^{64} \\
& \text { Esta es la historia } \\
& \text { del conde Pijapelada, } \\
& \text { que cuando se cabreaba } \\
& \text { a todos pol culo daba. }{ }^{65}
\end{aligned}
$$

62. Santa Brígida (Gran Canaria). Allí también se canta esta otra versión: «Estoy loco de contento / tengo pelos en el culo / por las noches me los cuento / y me salen ciento uno". Urbano (op.cit., p. 123) recoge una versión muy similar: «'Toy alegre, 'toy contento, / tengo pelos en el culo, / me los cuento por la noche, / ¡tengo ciento veintiuno!».

63. Quintillas de Manrique en controversia a tres con Barranco y Fernando, todos ellos improvisadores del Poniente almeriense.

64. Candeal, op. cit., p. 55.

65. Asturias (Suárez/Ornosa, op. cit., p. 208). 
Claro que la inversión del orden carnavalesca demanda que el que esté abajo se revuelva y sodomice al que está en la cúspide. De ahí que en el contexto de la minería leonesa se cante:

$$
\begin{aligned}
& \text { En el pozo de Sotillos } \\
& \text { había un mangante } \\
& \text { que quería dar por culo } \\
& \text { al vigilante. } \\
& \text { El vigilante, como no era tonto } \\
& \text { y entendía un poco más, } \\
& \text { le quería dar por culo } \\
& \text { al capataz. }
\end{aligned}
$$

Si el culo de la mujer está para taparlo con un rabo, como nos comentaba un mozo verderón en Sevilla, el del hombre está para resguardarlo. Ni un supositorio ha de desvirgar el sacrosanto agujero, como deja claro un cuentecillo recogido por Juan de Timoneda [1520-1583 $]^{67}$. El hombre ha de estar alerta, pues su masculinidad corre siempre el peligro de volver al útero materno y a la femineidad:

$$
\begin{aligned}
& \text { Si quieres andar tranquilo } \\
& \text { por calles y callejones } \\
& \text { ponte una chapa en el culo } \\
& \text { y un candil en los cojones. } \\
& \text { Si } \\
& \text { Si cruzas el arrabal } \\
& \text { y el arrabal está oscuro, } \\
& \text { échate la mano atrás } \\
& \text { o te darán por culo. }{ }^{69} \\
& \text { Cuando yo voy a mear } \\
& \text { le pido a San Cayetano } \\
& \text { que no me ponga en el culo } \\
& \text { lo que yo tengo en la mano. }
\end{aligned}
$$

El sodomizado es el no-hombre, que expone en el fondo su naturaleza sumisa, femenina y animal, a cuatro patas.

$$
\begin{aligned}
& \text { Si te cuentas cuatro huevos, } \\
& \text { no te creas Superman, } \\
& \text { es que estás a cuatro patas, } \\
& \text { te están dando por detrás. }{ }^{71}
\end{aligned}
$$

66. Urbano, op.cit., p. 141.

67. J. Timoneda, J., 1990, Buen Aviso y Portacuentos; El Sobremesa y Alivio para Caminantes; Cuentos (Joan Aragonés), Espasa-Calpe, Madrid, 1990, pp.79-80.

68. Madrid. Hay versiones similares: «Si quieres vivir feliz, / si quieres vivir contento, / ponte una chapa en el culo / cuando vayas a Agrigento" (Urbano, op. cit., p. 141).

69. Urbano op. cit., p. 141. El último verso debería ser «o te darán por el culo».

70. Las Palmas de Gran Canaria. Es copla derivada del dicho muy extendido: «San Cayetano, san Cayetano / que nunca tenga en el culo, / lo que tengo ahora en la mano».

71. Santa Brígida (Gran Canarias). 
Si lo que puede entrar en el ano masculino feminiza, lo que sale de él se asocia al más vil de los placeres.

\title{
Coprofilia EN VERSO: DE LOS PLACERES SIN PECAR...
}

La defensa hiperbólica del cagar y el peder es un género humorístico muy divulgado, tanto en la literatura de tradición oral, como en la escrita, culta. El ejemplo más célebre es el opúsculo de Quevedo titulado Gracias y desgracias del ojo del culo (1620-1626), que a finales del siglo XIX y principios del XX aún seguía publicándose en pequeños libritos, junto a otras obras escatológicas como la Defensa del pedo del erudito Manuel Martí (Oratio pro crepitu ventris, 1737). El siglo XIX, especialmente su segunda mitad, vivió una auténtica explosión de literatura escatológica de consumo popular, como demuestran los numerosos textos que nos han llegado en pliegos de cordel. Muchas de estas composiciones -como la Licencia para peder ${ }^{72}$ - venían a exaltar las bondades y placeres de lo que acontece en el retrete o la libertad gozosa de defecar al aire libre ${ }^{73}$. Copleros y trovadores populares crearon también las suyas, aunque solo excepcionalmente nos han llegado, cuando alguien las recogió por escrito. Así, por ejemplo, la larga composición que comienza "Cagar, oh, placer divino", que corre por las páginas webs y los blogs más licenciosos, sabemos que es creación de un vate popular de La Hayuela (Cantabria), de nombre Indalecio Zabala $\mathrm{Masio}^{74}$. Otras son recitadas por doquier, aun si se desconoce su autor ${ }^{75}$.

Además de estos largos discursos en forma de cartas, cantos o poemas, el elogio de las excreciones anales constituye un género muy divulgado en el cancionero popular, como en este conocido fandango andaluz:

\author{
Una mierda en un camino \\ se debe de respetar, \\ que una mierda representa \\ a un hombre que fue a cagar \\ y si no caga revienta. ${ }^{76}$
}

72. Fechada de 1704, en ella un tal Pedro Rodríguez de Montánchez, profesor de medicina, concede licencia al poseedor de la hojilla (que podría poner su nombre) para peder a su antojo. El paródico certificado médico para ventosear tuvo reiteradas impresiones en los siglos XVIII y XIX.

73. Una de las más divulgadas lleva por título Virtudes del Cagar. Nuevo discurso pronunciado en Cátedra cagatora de la Universidad de Ensulamanca: por Macario Cagón (Reus, Almacenes La Fleca). Otro pliego de cordel catalán contiene en siete páginas un sermó titulado Virtuts del Cagar. Corretgits y aumentats - per una colla de gats (Reus, Joan Gracu), en el que se incluye una composición en cuartetas titulada Fatigas d'un viatjánt al cagarse als pantalons. Hubo también textos mucho más largos, impresos en pliegos de fácil acceso y económicos. Así, por ejemplo, $\mathrm{La}$ Pedomanía: colección de aires particulares emitidos en todos los tonos, por un Flatulento (Talavera, Imprenta de Rubalcaba, 1891), de 40 páginas, que incluye Los amores de Pedorrera. Pasillo cómico en un acto y varios pedos.

74. Manuel Garrido Palacios la recoge en De viva voz. Romancero y cancionero al paso, Valladolid, Castilla ediciones, 1995, p. 63.

75. Véase Suárez/Ornosa op. cit., p. 245-248.

76. Urbano, op. cit., p. 14. 
En ocasiones, el elogio del defecar se recita como una retahíla, tal cual la hemos escuchado en Sevilla:

$$
\begin{aligned}
& \text { De los placeres sin pecar }{ }^{77} \text {, } \\
& \text { el más dulce es cagar, } \\
& \text { con un periódico extendido } \\
& \text { y un cigarrillo encendido, } \\
& \text { queda el culo complacido } \\
& \text { y la mierda en su lugar. }
\end{aligned}
$$

Pareciera que el placer de defecar aumentara uniéndolo a otros usos varoniles, como fumar:

$$
\begin{aligned}
& \text { Si vas al campo a cagar, } \\
& \text { lleva el cigarro encendido; } \\
& \text { cagarás y fumarás } \\
& \text { y estarás entretenido. } \\
& \text { Si quieres cagar a gusto, } \\
& \text { echa un cigarro cagando; } \\
& \text { con el humo del cigarro } \\
& \text { sale la mierda zumbando. }
\end{aligned}
$$

No extraña que hayamos oído a un viejo castellano, a la par que criticaba el uso de colonias y perfumes en el hombre como un signo de afeminamiento, defender enérgicamente que "el hombre solo debe oler a tabaco y a mierda».

Para entender el elogio jocoserio del defecar, no hay que olvidar que la deposición es consecuencia ineludible del placer secularmente exaltado por las clases populares en tiempos de fiesta: el comer. En un ingenioso libro coprofílico, Amaro Carretero recuerda cómo en su pueblo natal de La Mancha, existía un lugar prefijado donde los vecinos acudían a aliviar sus necesidades fisiológicas, en parte como pública exhibición de que habían disfrutado de un previo banquete:

Cuando veías a un vecino cagar en Los Quiñones pensabas con envidia: «Ese comió ayer». Para eso se cagaba allí, para eso cagábamos allí, para que se supiera que habíamos comido y se nos tuviera envidia [...]. Había veces, en la época de la matanza, por Semana Santa y en las tornabodas, en que podían admirarse hasta diecisiete cagadores que alineados con toda formalidad dejaban testimonio fehaciente de que ayer habían comido $^{79}$.

Eran los años del hambre en la España de la posguerra, cuando en los pueblos solo los señoricos tenían retrete privado en las casas y la mayoría de campesinos defecaban junto a mulos y asnos en el corral, para abonar después los campos. El esporádico hartazgo pantagruélico generaba una descomunal excreción, que se

77. Es esta una de las composiciones coprofílicas más divulgadas en España, con múltiples variantes: «De los placeres sin pagar» o "De los gustos sin pecar / el mejor es el cagar...», como está impreso en la contraportada de Gracias y desgracias de el ojo del culo; Los perfumes de Barcelona (Canarias, Imprenta de D. L. Montarich, 1875).

78. Ambas de La Mancha (Carretero, op. cit., p 149).

79. Op.cit., pp. 232-233. 
vivía con una ambigua satisfacción. Por eso, en muchos pueblos -Fuenlabrada de los Montes (Badajoz), por ejemplo- aún se dice:

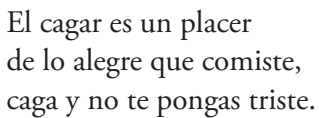

No menos conocidas son las composiciones que recuerdan la igualdad intrínseca del hombre, sujeto a las mismas necesidades bajas, independientemente del status y riqueza, de la misma manera que la medieval danza de la muerte venía a resaltar nuestro común destino.

Cagar es un placer;
de cagar nadie se escapa,
caga el rey, caga el Papa,
caga el buey, caga la vaca,
y hasta la seńorita más guapa,
hace sus bolitas de caca.
Viene el perro y lo huele,
viene el gato y lo tapa.
Total, en este mundo de caca,
de cagar nadie se escapa. ${ }^{80}$

Aunque hasta lo más cotidiano encierra sus riesgos, ya que hay quien, ante un súbito apretón, se olvida de coger papel o, siquiera, una piedra que esté a mano:

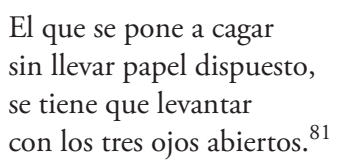

Si son legión las coplas que redimen la excreción de su secular estigma, no menos encendidas son las que, en idéntica y festiva inversión del orden, se recrean defendiendo hiperbólicamente las ventajas del libre ventosear. También aquí el mozo ha sido más dado a hacer de la flatulencia un recurso cómico, en el contexto tabernario y festivo de reunión de iguales, donde se mezclan los chistes verdes, las anécdotas obscenas y todo género de comentario escatológico. Así, resulta comprensible que fuera precisamente en ciertos ritos de paso-como en los quintos- y en todo caso en el contexto pandillero juvenil, donde se juegue a

80. Con distintas versiones, se canta o recita en toda Espańa, en lugares tan distintos como Soria, Cádiar (Granada) o Gárgoles de Abajo (Guadalajara). En Fuenlabrada de los Montes (Badajoz), se dice: «Del cagar nadie se salva: / caga el rico, caga el Papa, / pero a mí me gusta cagar en alto / y ver la mierda pegando saltos / y removerla con un palito, / como si fuera chocolatito» (J. Rodríguez Pastor, E. Alonso Sánchez, E. Ortiz Balaguer, «Unas notas sobre el folklore obsceno", Revista de Folklore, 20b, 236, 2000).

81. Sevilla. Versiones similares se cantan en pueblos de La Mancha (Fraile op.cit., p. 149) y Extremadura, como Valdecaballeros (Badajoz): «El que se pone a cagar / y no tie[ne] la piedra al perto / luego tiene que andar / con los tres ojos abierto»; o Villanueva de la Vera (Cáceres): "Todo aquel que va a cagar / no lleva papel dispuesto, / lo tiene que ir a buscar / con los tres ojos abiertos». 
hacer del cuesco un modo de expresión de la libertad, el espíritu contestatario, la valentía de romper con las convenciones sociales (especialmente con el decoro y el recato femenino), y por encima de todo, la defensa de lo carnal. Son innumerables las coplas pedorreras de mozos que cualquier joven recuerda:

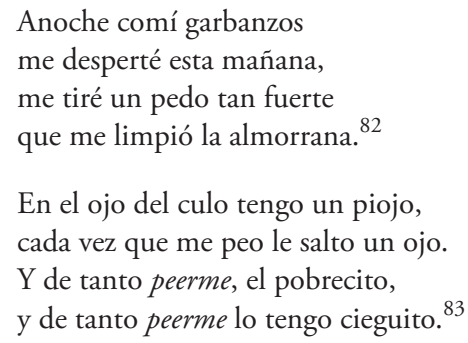

Dado el mayor recato exigido a las mujeres, son satíricas las coplas en que se les acusa a ellas de ser la fuente del pedo. En algunas canciones solo se sugiere indirectamente, como en esta cuarteta asturiana:

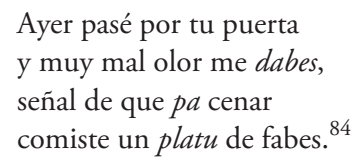

En otras, el infame aire es tan explícito como la sátira. Al igual que ocurría con el culo y los excrementos, cuando el ventosear se asocia a la fémina el resultado es invariablemente la burla de las maneras groseras.

$$
\begin{aligned}
& \text { La Tomasa, cuando amasa } \\
& \text { sin chaqueta ni jubón, } \\
& \text { se echa pedos en la masa } \\
& \text { y se rasca el pimentón. } \\
& \\
& \text { Las mocinas de mi pueblo } \\
& \text { son piquenas, barrigudas, } \\
& \text { cuando suben cuesta arriba } \\
& \text { tiran pedos como burras. }
\end{aligned}
$$

Pero no hay que olvidar la ambivalencia del realismo grotesco, que juega a mezclar lo bajo y lo alto, degradando lo más sublime y viceversa, de ahí que encontremos muchas de estas coplas en el contexto amatorio, que en tiempo de fiesta y licencias demanda sustituir los románticos suspiros por la degradación escatológica:

82. La Rinconada, Sevilla.

83. Especialmente los dos primeros versos están muy difundidos por toda España. Han sido recogidos, por ejemplo, en Cáceres (Rodriguez Pastor et al., op.cit., p. 2000).

84. Suárez/Ornosa op. cit., p. 134.

85. Urbano op. cit., p. 194. Obsérvese, de nuevo, la asociación a los alimentos agrarios.

86. Asturias (Suárez/Ornosa, op. cit., p. 72). Versiones: «Las mocitas de mi pueblo / son bajas y barrigudas, / cuando suben escaleras / tiran pedos como burras» (Candeal, op. cit., p. 40). 


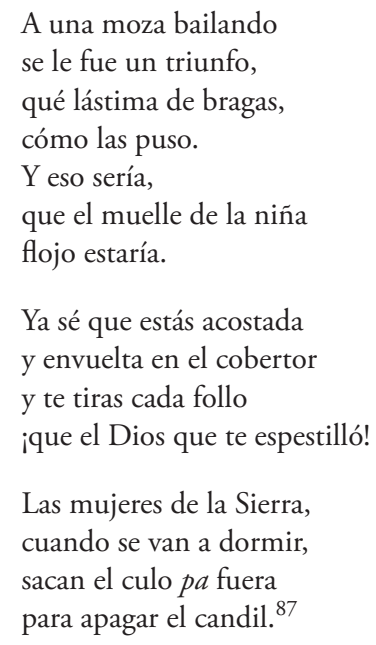

Un refrán asturiano («Vede, golosa; vede, pedere; no puede vedar ventanera») sugiere que es más fácil aguantar a la pedorra y a la golosa que a la ventanera, pero esta no solo está asociada en nuestro refranero a la putería, sino también al pedo: «Moza ventanera, o puta o pedera» ${ }^{88}$. Así, pues, si las deyecciones son exaltadas como placer en el mozo, en el caso de las mujeres, se torna afrenta grotesca, si bien, como todo lo tocante a la carne y en general al placer, nunca desaparece del todo la ambigüedad. Pero la diferencia en cuanto a los sexos es evidente. Al hombre no se le escapa un pedo, sino que lo utiliza como perfumado dardo, acompańando el sonoro trueno con un $" P a$ ti y $p a$ tu hermana», como he escuchado en La Rinconada (Sevilla), en el contexto de un entrenamiento futbolero de juveniles. No extraña que la deposición constituya un arma satírica utilizado por el varón despechada.

\section{LA LUCHA DE SEXOS: EN TU PUERTA ME CAGUÉ...}

Que le den a uno por culo o que le manden a la mierda son ambos juegos del lenguaje que se conjugan de las más variadas y ambivalentes maneras, desde el insulto hasta el comentario amistoso en tono jocoserio. Claro que la broma tiene múltiples matices. Que los mozos defequen a la puerta de donde vive alguna autoridad -el cura, el cacique, el alcalde, el médico- ha sido chanza muy extendida especialmente en tiempo de Carnaval. Durante mi trabajo de campo en la Alpujarra, se armó un gran revuelo en Murtas (Granada) cuando un joven contestatario y comunista dejó su pestilente y anónimo regalo a la puerta del que había sido un caciquillo rural de la Falange. La literatura del Siglo de Oro, especialmente la picaresca, recoge episodios semejantes, o más

87. Estas tres últimas en Urbano (1999: 14).

88. A. de Barros, Refranero español. Colección de ocho mil refranes populares, ordenados, concordados y explicados; precedida del Libro de los Proverbios morales, edición y recopilación explicada y ordenada por José Bergua, Madrid, Ediciones Ibéricas, 1961: 292. 
típicamente en contextos donde el personaje miserable es sometido a todo tipo de degradación burlesca. Bastará recordar lo que acontece al protagonista del Buscón de Quevedo, cuando llega a Alcalá. Los estudiantes le motejan de pestoso, le cubren de gargajos, y le arrojan trapos sucios; el mesonero y su amo le propinan por su parte una buena tunda de porrazos y repelones, aunque aún le espera la broma más pesada: uno de los criados defeca en su cama, y el pobre Pablos se embadurna de mierda al arroparse ${ }^{89}$.

Más frecuentemente aparece en la lírica popular esta escatológica manera de chanza asociada al desamor, el despecho y el inevitable destino de que no todos sean correspondidos. A lo largo y ancho de la Península son conocidas ciertas coplas que dan comienzo invariablemente por "en tu puerta me cagué", como las que cantan los mozos de Gárgoles de Abajo (Guadalajara) en la fiesta primaveral de los Mayos:

En tu puerta me cagué creyendo que me querías; ahora que no me quieres, dame la mierda que es mía. ${ }^{90}$

En tu puerta me cagué porque me vino la gana; ahí tienes ese clavel pa que lo huelas mañana. ${ }^{91}$

El motivo es antiguo, pues ya Correas recoge en su Vocabulario (1627) una copla similar:

$$
\begin{aligned}
& \text { Pues que no te puedo ver, } \\
& \text { vida, y cágome a tu puerta, } \\
& \text { porque tengas que barrer } \\
& \text { y coger en una espuerta. }{ }^{92}
\end{aligned}
$$

En el fondo, supone una versión disparatada sobre un tópico antiquísimo: la reclamación de los dones regalados, tras la ruptura amorosa, del que hay notables ejemplos, como los versos que recoge Gonzalo Correas en su Arte de la lengua castellana y española:

89. F. de Quevedo, La vida del Buscón, edición de Fernando Cabo Aseguinolaza, estudio preliminar de Fernando Lázaro Carreter, Barcelona, Crítica, 1993, pp. 85-91.

90. Es copla muy extendida. Se canta también, por ejemplo, en Venta del Moro (Valencia), Fuenlabrada de los Montes (Badajoz), en diferentes pueblos de La Mancha o en Cantabria. La recoge, también Urbano (op. cit., p. 16). Por cierto que, de la misma manera, se afrenta meando, como atestigua la copla que hemos oído en los diablos de Abejera de Aliste (Zamora), una mascarada de Año Nuevo en que tres personajes carnavalescos - dos ciegos y un gitano- cantan coplas obscenas y escatológicas: «Cuando pasé por tu casa / tu madre me llamó feo / la próxima vez que pase / saco la chorra y la meo».

91. Toledo (A. Gómez Moreno, "Margit Frenk y su Nuevo corpus», Revista de Filología Española, 87, 2007, 187). Urbano (op.cit., p. 15) recoge la misma versión, a la que se añade un quinto verso: «cuando salgas a barrer». Hay versiones por doquier: «En tu puerta me cagué / cuando tu padre salió / ahí te dejo ese clavel / pa que lo huelas mi amor» (Las Palmas de Gran Canaria).

92. Correas op. cit., p. 663; Margit Frenk op. cit., p. 1415; NC 1987. 
Eché leña en tu corral, pensando casar contigo; dame mi leña, te digo, que no me quiero casar. ${ }^{93}$

No pocas de las canciones escatológicas y obscenas son en realidad contrafacta que remedan alguna otra composición, normalmente amorosa y, en todo caso, libre de palabras malsonantes y sentidos escandalosos. Son coplas de mozos que invierten los códigos de cortejo con la mujer, y los de cortesía y respeto a los que están obligados para con los padres de ella.

Anda diciendo tu madre que yo me muero por ti, vete a la mierda tú y ella, cágome en ella y en ti. ${ }^{94}$

Una vez tuve una novia, mi suegra no me quería, le dije con disimulo:

- ¡Ahí tiene a su María y se la mete en el culo! ${ }^{95}$

La imagen grotesca se usa a veces para escarnecer a ambos suegros, lo que se canta, como siempre, en el contexto de fiestas de mozos, como antes se entonaba por los quintos:
A la puerta de mi novia qué bobada vi yo un día: su padre tiraba pedos, su madre se los olía. ${ }^{96}$
Niña no te tires pedos que es de mala condición, guárdalos para tu padre y la madre que te parió. ${ }^{97}$

La animadversión a la suegra -uno de los sentimientos más extendidos, casi considerado un universal cultural por los antropólogos- ha dado pie a imaginativas coplas, que hacen las delicias del joven que se ve obligado a soportarla:
A mi suegra le han pillado robando unas aceitunas, la obligaron a meterse, por el culo, una a una. ${ }^{98}$

93. Frenk op.cit., II, p.1402. Versiones muy semejantes a esta han sido recogidas modernamente (F. Álvarez Curiel, Cancionero Popular Andaluz, Málaga, Arguval, 1991, 161).

94. Asturias.

95. Priego (Alcalá, op. cit., p. 639).

96. Candeal op. cit., p. 91.

97. Candeal op. cit., p. 47.

98. Candeal op. cit., p. 117. 
Cuando me pongo a cagar y me acuerdo de mi suegra, no sé qué coño me pasa que no me sale la mierda. ${ }^{99}$

En mucha menor medida, también las mozas replican a veces con similares dardos de desprecio, de norte a sur:

\author{
Vete a la mierda, buen mozo \\ yo me cago en tu salero, \\ otros mejores que tú, \\ me los dan y no los quiero. ${ }^{100}$ \\ Ya se acabó la aceituna, \\ ya se acabo el alboroto; \\ vaya mi novio a la mierda \\ que en mi pueblo tengo otro. ${ }^{101}$ \\ Me han dicho que tienes otra \\ que la quieres más que a mi; \\ quiérele mucho y aprisa: \\ ¡me cago en ella y en ti! ${ }^{102}$ \\ Si me quieres dímelo \\ y si no, vete a la mierda. \\ Otros mejores que tú \\ he tenido entre las piernas. ${ }^{103}$
}

Pero dado que, como hemos visto, el defecar se asocia también al placer, en ocasiones las canciones juegan con el secular sentido ambivalente, Si Quevedo cita un proverbio de su época, «Más te quiero que a una buena gana de cagar»"104, hoy en día se entonan piropos estrafalarios, en ocasiones con sentido paródico .

Te quiero como la mierda, no te olvido ni cagando, cada pedo que me tiro, es un beso que te mando. ${ }^{105}$

99. La Mancha (Carretero, op. cit., p. 129).

100. Asturias (Suárez/Ornosa, op. cit., p. 108). Hay variante: «Vete a la mierda, buen mozo, / yo me cago en tu salero / en tu padre y en tu madre / y en ti mismo si yo quiero» (idem 108).

101. Andalucía (E. Jiménez Díaz, Erotismo y humor en las coplas flamencas, Barcelona, Libros PM, 1997, 49).

102. Úbeda. En Castrocalbón, Burgos, se canta esta versión: «Mi novio tiene otra novia / que la quiere más que a mí; / quiérela mucho y aprisa, / me jodo en ella y en ti» (Manzano, op. cit., 1993, p. 74).

103. La Mancha (Carretero, op. cit., p. 134). Hay versiones masculinas similares: «Si me quieres, dímelo. / Y si no, vete al carajo, / que otras, mejores que tú, / las he tenido debajo» (Herreros, Soria).

104. Op.cit., 1993, p. 362.

105. Almería, aunque muy extendida. 
Cuando te veo, me peo;

mira para mí qué suerte.

Y el día que no te veo,

me estoy cagando por verte. ${ }^{106}$

El equívoco es aquí la base del juego verbal, como en otras coplas que hemos visto más arriba, y que mezclan el agasajo amoroso y algún acto fisiológico que lo rebaja ${ }^{107}$. Pero no hay que olvidar que esta ambivalencia deriva precisamente de una arcaica concepción, según la cual el lugar de lo ínfimo y la destrucción -la mierda, la tierra- es también donde se engendra lo nuevo. El culo es, en términos bajtinianos, la tumba corporal a la que se arroja al humillado, pero también el lugar vinculado a la satisfacción de las necesidades más básicas y el sustrato del que renacerá renovado. El "te quiero como la mierda» no es solamente negación e insulto, de ahí la risa que provoca, pues en el fondo se mezclan -como ocurre en el amor y el sexo- lo alto con lo bajo en esa tradición que tiene algunos de sus más fieles exponentes en nuestra literatura del Siglo de Oro, y que convivió, sincretizando, con la que componía el pueblo en la plaza y la taberna. Juan Goytisolo ${ }^{108}$ recuerda, al tratar la obsesión excremental de Quevedo, cómo este recrea el tópico del inter urinas et faeces nascimur: «la vida empieza en lágrimas y caca» ${ }^{109}$. A Quevedo le gusta hacer burla equiparando el ojo del culo con los de la cara ${ }^{110}$, subvirtiendo así la sublimación del rostro de la amada, de la misma manera que los mozos de Villanueva de Vera (Cáceres) juegan a poner en paralelo la cara y el culo, en el fondo lo alto y lo bajo, lo que está delante y lo que está detrás:

\author{
Aunque no te lo he visto \\ me lo figuro: \\ del color de la cara \\ tienes el culo.
}

Frente al amor platónico, sublime, desgarrado, ciertas coplas de ronda han preferido destacar nuestra más rudimentaria animalidad. Al fin y al cabo, el cuerpo ha sido en la tradición católica el campo de batalla entre Dios y el diablo, y el pueblo se ha deleitado en tiempo de fiesta guińándole el ojo al demonio y aliándose con él para tintar el mundo entero, siquiera por unos días, de corpóreo éxtasis.

106. Fuenlabrada de los Montes, Badajoz (Rodríguez Pastor, op.cit.).

107. «Eres hermosa en extremo / y eso bien lo sabes tú, / que cuando vas a mear / haces cla, cle, cli, clo, clu» (Candeal, op. cit., p. 34).

108. J. Goytisolo, Disidencias, Madrid, Taurus, 1992, pp. 156-157.

109. F. de Quevedo, Obra poética, Blecua, J. M. ed., 3 vols., Madrid, Castalia, 1969-1971, $\mathrm{n}^{\circ} 535$.

110. «La llaneza de tu cara / en nada lo disimulo, / pues profesora de culo, / si un ojo no le sobrara» (op. cit., p. 210). 


\title{
LA PICAÍlLA FEMENINA: CON UNA ALPARGATA MIERDA...
}

No solo han servido los excrementos y las ventosidades como afrenta verbal y lúdica entre los sexos. En el Campo de Dalías almeriense, y mientras las mujeres limpiaban la uva sentadas en grupos, estas tenían costumbre, hasta hace unas décadas, de lanzarse todo tipo de chocarrerías en coplas de picaílla, según terminología del lugar:

\author{
Cántame de picaílla \\ que yo te contestaré: \\ con una alpargata $[\mathrm{de}]$ mierda \\ en la boca te daré. \\ Tú fuiste y te peiste \\ en la puerta de la escuela \\ y salieron los chiquillos: \\ ¡Santa Bárbara que truena!
}

Algunas coplejas son tan genéricas que pueden utilizarse en cualquier batalla verbal:

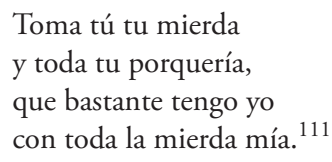

En el contexto de trabajo femenino, en estrecho contacto, las mismas canciones que hacen mella sobre la suciedad de la mujer son traídas a colación en unos intercambios de pullas en los que se competía, como nos han dicho, «en ver quién decía la burrá y la porquería más gorda». Sorprende que algunas de estas canciones estén divulgadas por muy diferentes lugares, lo que sugiere que estos juegos verbales han gozado de amplia aceptación.

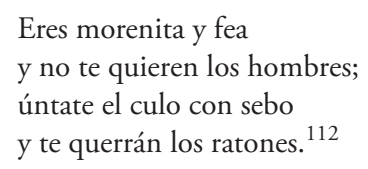

LO DEFORME Y CADUCO: UNA VIEJA SE PEYÓ...

Ya vimos que, para Bajtin ${ }^{113}$, la imagen grotesca deriva de una concepción que considera el cambio y la metamorfosis como un proceso siempre incompleto, inacabado, donde la muerte es imprescindible para que se produzca el nacimiento, tal y como acontece en el mundo natural agrario. La ambivalencia

111. Santa Brígida (Gran Canaria).

112. Fraile op. cit., p. 147. Otra versión cántabra: «Eres más fea que Picio / que no te quieren los hombres, / úntate el culo con queso / que te quieran los ratones» (Gomarín, op. cit., p. 60).

113. Op. cit., p. 28. 
de la muerte o del diablo produce tanto imágenes espantosas, como risibles, de la misma manera que los lamentos fúnebres se revuelcan junto con las bromas y chistes en ciertos momentos liminares ${ }^{114}$; en los velatorios, por ejemplo, cuando el muerto está a punto de transitar al otro mundo, pero aún se encuentra de cuerpo presente entre los vivos. Mientras en Sevilla he oído insultos tan originales como el de «ojalá que te mueras y te entierren con el culo $p a$ fuera $p a$ aparcar las bicicletas», en Chirivel (Almería) se canta:

\author{
El día que tú te mueras, \\ que te entierren boca abajo \\ con un sarmiento en el culo, \\ que te chupen los borrachos. ${ }^{115}$
}

Lo sucio, lo putrefacto, lo relacionado con el cadáver vuelve a la tierra de donde brota de nuevo la vida. La concepción del tiempo cíclico y dicotómico, unido al gusto por la degradación grotesca se hace patente en ciertas coplas que parecen aunar los dos polos antitéticos: el nacimiento y la muerte, la primera infancia y la decrepitud. Escribe Bajtin que «una de las tendencias fundamentales de la imagen grotesca del cuerpo consiste en exhibir dos cuerpos en uno: uno que da la vida y desaparece y otro que es concebido, producido y lanzado al mundo» ${ }^{116}$. Sus palabras resuenan en esta nana gallega:

\author{
Arrerú, arrerú, \\ cunha tranquiña no cu; \\ morrerán os velhos todos \\ quedaremos eu e tu. \\ Arrerú, arrerú. ${ }^{117}$
}

Nada es perfecto, exacto, imperecedero, mucho menos el cuerpo. En la concepción clásica, el cuerpo perfecto es el que está lejos del inicio (el nacimiento, la infancia) y el final (la vejez, la muerte), pero la cultura popular ha enfatizado siempre los umbrales, especialmente en ciertos momentos del año en que se transita de un lugar o estado a otro. El cuerpo grotesco está siempre impregnado de vida y muerte por igual, al igual que todo lo que existe en el mundo. El mundo -lo exterior- permeabiliza el cuerpo -lo interior- de tal manera que los ritmos vitales de la naturaleza están en consonancia con los del cuerpo; entran, por así decirlo, a través de sus orificios. El hombre no solo desea expresar, sino propiciar esos cambios necesarios, contribuyendo

114. Según Van Gennep (Los ritos de paso, Madrid, Alianza editorial, 2008, p. 25), los ritos de paso incluyen tres estados: ritos preliminares (separación), liminares (margen) y postliminares (agregación).

115. Otras rajas también se abren a la muerte: «Una moza murió en Cádiz / y dejó en el testamento / que la entierren para arriba, / con el silabario abierto» (Candeal, op.cit., p. 63).

116. Op.cit., p. 30.

117. Frenk y Pedrosa («Nuevas supervivencias de canciones viejas», Revista de Literaturas Populares, VIII, 2, 2008, p. 310). La canción se encuentra ya en tiempos de Gil Vicente: «Ru, ru, menina, ru, ru, / mouram as velhas e fiques tu, / coa tranca no cu» (Frenk, op. cit., II: 1482; NC 2048). 
al fin del mal tiempo y el tiempo maligno: el frío invierno, el reino de la oscuridad y el miedo, de la esterilidad y la muerte. Así, la defenestración simbólica de lo viejo es un recurso necesario para propiciar la renovación del cosmos en una concepción del tiempo cíclica y bipolar, de ahí que estas coplas sean tan frecuentes en el período carnavalesco entre diciembre y febrero, y muy especialmente entre Navidad y Reyes, cuando se deja el año viejo para entrar renovado -esperanzado- en el año nuevo. La degradación grotesca de lo decrépito se incita carnavalescamente, de la misma manera que se exagera cómicamente lo sucio, lo gordo, lo deforme y monstruoso, todo lo cual viene a reconciliar el cuerpo con la tierra. Frente a la imagen de la candorosa anciana, al pueblo le ha gustado presentarla en algunos contextos festivos -la Navidad, el Carnaval- sin depurarla de los despojos del deterioro y la necesaria fealdad y repulsa que vendría a oponerse, de manera natural, a la belleza y el brío del mocerío, lo nuevo y puro. Es precisamente en las protuberancias, excrecencias y orificios -barriga, nariz, ojos, boca, pechos, vagina, ano- donde el tiempo pide a gritos la renovación, que el pueblo no solo aplaude, sino contribuye a crear:

$$
\begin{aligned}
& \text { De la fuente mana el agua } \\
& \text { y de la junquera el junco, } \\
& \text { y del culo de las viejas } \\
& \text { salen los abejarucos. }{ }^{118} \\
& \text { Una vieja muy revieja } \\
& \text { de noventa navidades, } \\
& \text { tiene pelos en el culo } \\
& \text { y dice que son lunares. } \\
& \text { Una vieja en un corral } \\
& \text { estaba friendo un huevo } \\
& \text { le saltó una chispa al culo } \\
& \text { y mandó tocar a fuego. }{ }^{120}
\end{aligned}
$$

El ano, como la vagina ${ }^{121}$ de la vieja, es un orificio más de la muerte, que de la vida, aunque sea precisamente esta ambivalencia lo que genere la comicidad del realismo grotesco. Bajtin recuerda las figuras de terracota de Kertch, conservadas en el Museo Hermitage de Leningrado (San Peterburgo), que representan ancianas embarazadas, en las cuales se destacan a la vez su vejez y su embarazo, mientras ríen: «este es un tipo de grotesco muy característico y expresivo, un grotesco ambivalente: es la muerta encinta, la muerte que concibe» ${ }^{122}$. Así resultan comprensibles canciones aparentemente surrealistas como la que se entona en Llamazares, León:

118. Villanueva de la Vera (Cáceres).

119. Valle de Polaciones, Cantabria (Gomarín, op. cit., p. 81).

120. Urbano op.cit., p. 193. Hay versiones por toda la geografía. En Asturias, por ejemplo, se canta: «Una vieya n`un carrálicu / taba asando un cordéricu / saltó-y una chispa al cúlicu / y vinieron los bombéricus» (Suárez/Ornoso, op. cit., p. 179).

121. «Una vieja en un corral / se lo miraba y decía: / qué feo te vas quedando / rapacuartos de mi vida» (Valladolid).

122. Bajtin, op.cit., p. 29. 
Una vieja de cien años

y otra de ciento cincuenta

daban de mamar a un niño

que tenía ciento ochenta. ${ }^{123}$

Especialmente grotesca es la imagen de la vieja (y en menor medida el viejo) que caga, mea o pede, motivo habitual en los villancicos navideños, cuando el vino, el anís o el orujo han ayudado a crear un ambiente de licencia festiva. Algunas de las canciones de viejos escatológicos se remontan al siglo XVII, como la del «mal viejo desvariado» del Cancionero de Horozco:

$$
\begin{aligned}
& \text { Aunque soy viejo cuitado, } \\
& \text { mis tres vegaditas hago. } \\
& \text { Para quitar el deseo, } \\
& \text { antes que me acueste meo, } \\
& \text { estando en la cama peo, } \\
& \text { cuando me levanto cago; } \\
& \text { mis tres vegaditas hago. }{ }^{124}
\end{aligned}
$$

Margit Frenk recoge en su Nuevo Corpus de la Antigua Lirica Popular Hispánica alguna canción escatológica, muy parecida a las que hemos oído en las mascaradas de año nuevo de Abejera de Aliste (Zamora), y en otras fiestas navideñas donde se representan pugnas violentas, plenas de obscenidad y escatología, entre diablos, ciegos, gitanos, madamas y otros personajes que se prestan a la dramatización de la lucha entre el bien y el mal, lo nuevo y lo viejo, la fecundidad y la esterilidad, la vida y la muerte.

$$
\begin{aligned}
& \text { Una viexa se meó } \\
& \text { en la canal de un texado; } \\
& \text { el sacristán, que lo vio, } \\
& \text { fuera a tocar a nublado. }{ }^{125}
\end{aligned}
$$

El motivo, la estructura, el sentido, incluso el primer verso de la licenciosa copla, es similar a las versiones que aún hoy se entonan como villancicos, y aun en otros momentos del año, en reuniones de estudiantes y jóvenes en sus fiestas.

$$
\begin{aligned}
& \text { Una vieja se cagó } \\
& \text { al pie de un confesionario } \\
& \text { y el sacristán lo cogió } \\
& \text { creyendo que era un rosario. }{ }^{126}
\end{aligned}
$$

123. Manzano op.cit., 1993, p. 293.

124. Margit Frenk op.cit., II, p. 1354; NC 1897 B. Correas anota otra versión en su Vocabulario (Margit Frenk, op.cit., II, p. 1354; NC 1897 A).

125. Margit Frenk op.cit., II, p. 1400; NC 1957.

126. Sevilla, Salamanca, Granada. La copla ha gozado de mucha popularidad y hay versiones diferentes. En Villanueva de la Vera, el grupo folkórico independiente Velâhilë ha grabado: «Una vieja se cagó / al lao de un confesionario / y el sacristán lo cogió / pensando que era el rosario / y al cura se lo llevó» (C.D. El arroyo los Cagaos, 2003). 
En cada pueblo, la coplilla se ha aderezado con más o menos disparates, aunque siempre buscando la imagen grotesca ${ }^{127}$. Con idéntico sentido que las coplas del viejo o la vieja defecantes, la arrugada pedorra constituye una imagen más que repugnante, carnavalera, pues su atroz trueno provoca desastres rayanos en el surrealismo:

$$
\begin{aligned}
& \text { Una vieja tiró un peo } \\
& \text { al pie del canto la olla } \\
& \text { y salieron los garbanzos } \\
& \text { pidiendo misericordia. }{ }^{128} \\
& \text { Una vieja en la comedia } \\
& \text { tiró un soplo tan atroz, } \\
& \text { que apagó las candelillas, } \\
& \text { y mató al apuntador. }{ }^{129}
\end{aligned}
$$

Son legión las coplas de la vieja ventosa ${ }^{130}$. Para aumentar las connotaciones de suciedad, vileza y grosería, algunas coplas hacen del pedo un tiro asesino, cuya víctima es un animal de granja tomado por guarro, ínfimo, o incluso el propio demonio:

$$
\begin{aligned}
& \text { Una vieja muy revieja, } \\
& \text { más vieja que San Antonio, } \\
& \text { soltó un pedo en el infierno } \\
& \text { y mató treinta demonios. }{ }^{131} \\
& \text { Una vieja en una cuadra } \\
& \text { se echa un peo y mata un burro: } \\
& \text { pa que digan que las viejas } \\
& \text { no tienen fuerza en el culo. }{ }^{132}
\end{aligned}
$$

127. «Una vieja se cagó / en el boliche [de] una silla; / otra fue y se lo comió / creyendo que eran morcillas» (Villanueva de la Vera, Cáceres); «Una vieja fue a cagar / detrás de una platanera, / vino un perro por detrás / y se comió la habichuela» (Santa Brígida, Gran Canaria); «Una vieja se cagó / en un montón de salvao / y de cien kilos que había / no quedó más que un puñao (Alcalá del Río, Sevilla); «Una vieja se cagó / en lo alto de una antena / y la mierda se veía / por la segunda cadena (Villanueva de la Vera, Cáceres). «Una vieja se cagó / en el troncón de una higuera / y los higuillos bailaban / al son de la pedorrera» (La Mancha, Carretero, op. cit., p. 97).

128. Valle de Polaciones, Cantabria (Gomarín, op. cit., p. 80).

129. Andalucía (Jiménez Díaz, op. cit., p. 163).

130. «Una vieja se peyó / en un montón de salvaos, / de cien fanegas que había / no dejó más que un puñao» (Cáceres, Rodríguez Pastor, op. cit., p. 2000); "Una vieja se echó un pedo / a la sombra de una higuera, / y los chiquillos bailaban / al son de la pedorrera» (Venta del Moro, Valencia); «Una vieja se echó un pedo / arriba en la punta [del] Teide, / retumbó en La Orotava / y en Santa Cruz rompió el muelle (Tenerife).

131. Candeal, op. cit., p. 66.

132. Santa Brígida (Gran Canaria). Otra versión: «Una vieja muy revieja / con un pedo mató a un burro, / ¡vaya demonio de vieja, / cuánta fortaleza tuvo!» (Candeal, op.cit., p. 65). 
El gato, el cochino, la gallina, el gallo, el pollo, el buey, no hay animal que se libre del cuesco homicida de la vieja ${ }^{133}$. Un tópico no menos repetido es el de la vieja glotona, obligada a tremendas ventosidades tras hartarse de algún alimento, especialmente flatulento.

Una vieja se comió

20 kilos de judías

y estuvo toda la noche

¡qué cañón de artillería! ${ }^{134}$

Judías, tomates, manzanas, sardinas, mondongo, casi cualquier cosa -incluso el cemento- vale para plasmar la desmedida ingesta que ha de volver a la tierra, a través de otros orificios ${ }^{135}$. Para mayor énfasis grotesco, las canciones se alińan de guarrerías, como cuando la vieja o el viejo se rascan el culo u otras partes más íntimas:

\author{
Allá arriba en la montańa \\ hay un viejo cachirulo \\ que tiene las uñas negras \\ de tanto rascarse el culo. ${ }^{136}$ \\ Esa calle abajito \\ baja una vieja \\ arrascándose el culo \\ con una teja. ${ }^{137}$
}

133. «Una vieya n'un corral / tiró un pedo, mató un xato, / valga al demonio la vieya, / iqué grande tien el furacu!» (Asturias, Suárez/Ornosa, op.cit., p. 179); «Voy a contarles la historia / de un caso muy asesino / que una vieja en el chiquero / de un peo mató un cochino» (Huelva); «Una vieja en un corral / se ha tirao un peo mu gordo / ha matao siete gallinas / y al guarro lo ha dejao sordo" (Villanueva de Vera, Cáceres); «Una vieja en un corral / de un pedo mató tres pollos; / si no la sacan de allí / mata gallinas y todo» (Guzmán, Burgos, Manzano, op.cit., 2001, II, p.316); «Una vieja en un corral / de un pedo mató tres bueyes / y otra vieja le decía: / jodida, qué tino tienes» (Guzmán, Burgos, Manzano, op.cit., 2001, II, p.317).

134. Santa Brígida (Gran Canaria). Versión de La Mancha: «Una vieja se comió / kilo y medio de judías / y parecía su culo / un cańón de artillería» (Carretero, op.cit., p. 8).

135. «Una vieja se comió / 20 kilos de manzana / y estuvo toda la noche / con el culo en la ventana» (Santa Brígida, Gran Canarias); «Una vieja se comió / cinco kilos de tomates / y toda la noche estuvo / subiendo y bajando al váter» (Sevilla, Valladolid, aunque está muy extendida); «Una vieja se comió / de los tomates el momio, / no le entre una cagalera / que la lleven los demonios» (Candeal, op.cit., p. 66); "Una vieja se comió / una ristra de tomates / y estuvo toda la noche / - ¡Ay que se me enfonda el catre!» (Santa Brígida, Gran Canarias). «Una vieja se comió / medio kilo de sardinas, / y toda la noche estuvo / sacando del culo espinas» (Alcalá del Río, Sevilla), otra versión casi idéntica en el valle de Polaciones, Cantabria (Gomarín, op.cit., p. 80); «Una vieja se comió / kilo y medio de mondongo / y toda la noche estuvo / con el orinal al hombro» (Candeal, op. cit., p. 67); «Una vieja se comió / siete bolsas de cemento / y del pedo que se echó / construyó el ayuntamiento» (Santa Brígida, Gran Canarias): «Una vieja se comió / ciento cincuenta boronos, / no le entre una cagalera / que la lleven los demonios» (Valle de Polaciones, Cantabria, Gomarín, op. cit., p. 80).

136. Santa Brígida (Gran Canaria).

137. Villanueva de Vera (Cáceres). 
La vieja mustia, cuyas carnes se pudren, es, en mucho mayor medida que el viejo, el símbolo grotesco del mito del eterno retorno, pues es la mujer la que se asocia simbólicamente a la tierra, matriz y tumba a la vez. Unida a la sexualidad, la vieja se convierte en diana de todas las pullas, ya que la habitual censura moralista del apetito sexual femenino, típica en las culturas cristianas, se agudiza cuando la mujer es anciana, mostrándose por lo tanto dominada por instintos carnales, bajos, que solo habrían de ser lícitos y naturales en el caso del hombre, si acaso de la joven. Lo antinatural es monstruoso, diabólico, se sitúa en las antípodas del orden y lo correcto, y por lo tanto atrae ambivalentemente, como lo carnal. La unión en un mismo cuerpo de la estéril decrepitud y la ardiente sexualidad genera una de esas imágenes que, según Bajtin, son la base de la comicidad popular.

$$
\begin{aligned}
& \text { Una vella por foder } \\
& \text { casóuse con un gaiteiro, } \\
& \text { por el culo fo'l roncón, } \\
& \text { y pol carayu el punteiro. }{ }^{138} \\
& \text { Me casé con un viejo, } \\
& \text { viejo, viejete, } \\
& \text { comido de ratones } \\
& \text { hasta el ojete. }
\end{aligned}
$$

\section{LA SÁTIRA ANTICLERICAL: UN FRAILE ESTABA GAGANDO...}

Desde la Edad Media, han abundado las composiciones satíricas en que miembros del clero no solo se dan a todo tipo de placeres -comer, beber, dormir, fornicar-, sino que muestran las mismas necesidades fisiológicas que el común de los mortales. El defecar, como acción necesaria aunque sucia, ha sido tomado desde antiguo para humanizar y degradar carnavalescamente a quien aspira supuestamente a una vida espiritual, santa, noble, como si pudiera obviar las necesidades más mundanas, corporales. Como la muerte, cualquier elemento inexorable iguala, de ahí que refranes, chistes y canciones aludan a lo que asemeja a un campesino con el rey o el Papa, concluyendo que «sin cagar nadie se escapa», lo cual se entona en forma de canción en muchos lugares, como hemos visto. Por toda la Península, son frecuentes en el contexto festivo las coplas en que se airea aquello que avergüenza al religioso:

\footnotetext{
El curita de mi pueblo se lava él los calzones, para que no le vea el ama palominos y gorriones. ${ }^{140}$
} 
La mezcla de lo profano y lo sagrado es uno de los ingredientes clave de la comicidad popular, como lo es la inversión carnavalesca del orden, incluida la ridiculización (o la denuncia) de los valores de espiritualidad y ascetismo. Dado que la excreción es consecuencia del comer, el clérigo al que urge hacer sus necesidades forma parte de la sátira de la glotonería y, en general, del apego a los placeres materiales. Un buen ejemplo es una pieza dialogada conocida como Maitines, que se canta con mucha guasa en tono sacro en algunos pueblos de Jaén, y que hace sutil burla dentro de un género muy extendido de sátira anticlerical, que pone en la picota a las relaciones entre el cura o fraile y la barragana, ama u otra mujer, casada o no ${ }^{141}$.

-Vámonos a maitines mi doña Elena

vámonos a maitines con la linterna.

-¿Qué haremos en maitines padre fray Diego?

¿Qué haremos en maitines, qué haremos luego?

-Compraremos el pollo, mi dońa Elena, compraremos el pollo con la linterna.

$[\ldots]$

-Y después de comido el pollo, padre fray Diego y después de comido el pollo, ¿qué haremos luego?

-Cagaremos el pollo, mi doña Elena, cagaremos el pollo con la linterna.

-Y después de cagado el pollo, padre fray Diego, y después de cagado el pollo, ¿qué haremos luego?

-Nos acostaremos mi dońa Elena, nos acostaremos con la linterna...

Frecuentemente, los versos parodian no solo la música, sino también el lenguaje sacro, como ha sido santo y seńa de cierta literatura paródica desde la Edad Media, que incluye las misas de locos o misas báquicas.

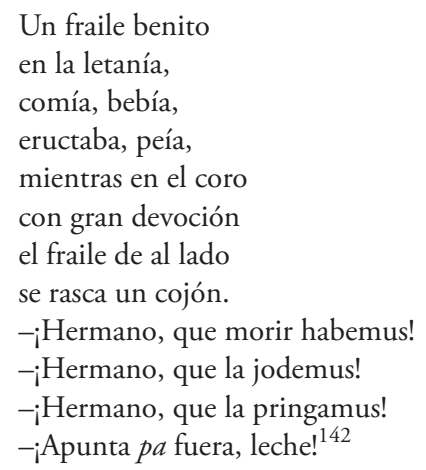

141. Tema muy divulgado, al que ya alude alguna cancioncilla burlesca del siglo XV, contenida en el Cancionero musical de la Colombina (Frenk, op. cit., 2006, p. 38-39; pp.650-670).

142. Urbano op. cit., p. 158-159. 
Más explícitas y punzantes son algunas coplas que unen a la sátira de la promiscuidad del clero, lo sucio y repulsivo:

El cura de la aldea

tiene almorranas

de sentarse en el poyo

con Feliciana. ${ }^{143}$

Y no faltan las muestras irreverentes en que frailes y curas se cagan en lo humano y lo divino:

$$
\begin{aligned}
& \text { Un fraile estaba cagando } \\
& \text { encima de una pared; } \\
& \text { pasó una monja y le dijo: } \\
& \text {-iqué borlas me gasta usted! }{ }^{144} \\
& \text {-iMe cago en Dios!, dijo el fraile } \\
& \text { en la puerta del convento. } \\
& \text { Y salieron to las monjas } \\
& \text { pa meterlo para dentro. } \\
& \text { Un } \\
& \text { Un cura se cagó en Dios } \\
& \text { a la puerta de la iglesia, } \\
& \text { y otro cura le reprende: } \\
& \text {-iCago en la hostia, qué bestia! }{ }^{146}
\end{aligned}
$$

En definitiva, las canciones burlescas con el clero, que ahondan sobre todo en sus dotes e inclinaciones sexuales, han dado para aliñarlas con motivos escatológicos, que rebajaban aún más, en ocasiones con singulares mezclas, como en esta copla asturiana:

$$
\begin{aligned}
& \text { Si quieres mexar, meixa, } \\
& \text { meixa na candilexa, } \\
& \text { si quieres cagar, caga, } \\
& \text { caga pela tu saya. } \\
& \text { Al de la monteruca, } \\
& \text { cagáron-y na chupa, }
\end{aligned}
$$

143. Cáceres (K. Schindler, Folk Music and Poetry of Spain and Portugal (Música y Poesia Popular de España y Portugal), Nueva York, Hispanic Institute in the United States, 1941, p. 18).

144. Valle de Polaciones, Cantabria (Gomarín, op.cit., p. 51). Una versión casi idéntica en Urbano (1999: 113). Otra versión: «Un fraile estaba cagando / al lado de una pared, / pasó una monja y le dijo: -iVaya huevos gasta usted!» (Candeal, op. cit., p. 143). En La Mancha se canta: «Un cura estaba cagando / a la sombra de un acebuche / y de lejos parecía / un palomo con dos buches» (Carretero, op. cit., p 12). Otras coplas anticlericales ponen en riesgo el órgano del fraile, por donde orina: «En la puerta del convento / había un fraile meando; / ha llegado un gato negro / y le ha estirado el rabo» (Fraile, op. cit. pp. 158-159); «Estando un fraile meando / en la puerta del convento, / vino la rata Comino / y le mordió el instrumento. / La rata, tira que tira, / el fraile llora que llora: / -Madrecita de mi alma / que me quedo sin pistola» (Rodríguez Pastor, op. cit.); «Un fraile estaba meando / a la sombra de un tomillo / y otro fraile le decía: / -¡Vaya mango pa un martillo!» (Guadalajara).

145. Antequera (Málaga).

146. Valle de Polaciones, Cantabria (Gomarín, op. cit., p.47). 
si el cura andaba a fabes por ente los maizales, si el cura andaba a figos, ¿qué farán los vecinos? ${ }^{147}$

\section{Conclusiones: SENTIDO DE LA LITERATURA OBSCENA-ESCATOLÓGICA POPULAR}

En ocasiones no hay ambivalencia alguna cuando mandamos a alguien a la mierda o a que le den por el culo. La escatología y la obscenidad es recurso de afrenta, insulto que envía al injuriado al lugar más ínfimo y que disfruta con la humillación del ofendido. Y sin embargo, cuando el culo hace su aparición en las canciones populares, es siempre en tono humorístico, y más aún carnavalero: conjugando, como aquí hemos visto, las diferentes facetas de uno de los órganos más ambiguos asociado por igual a la comilona, al coito, a la belleza -a la carne en su sentido lujurioso y de gula- como a lo sucio, pestilente, lo más bajo y ruin. Hemos recordado, con Bajtin, que en la concepción popular lo alto y lo bajo es topográfico (el cielo y la tierra) y corporal (el rostro y los órganos inferiores; vagina, ano, falo). Y que dicha dicotomía no es inequívoca, sino antes bien simboliza los dos polos antitéticos pero complementarios que mueven el mundo, de la misma manera que lo son el hombre y la mujer, el invierno y el verano, la vida y la muerte. La ambivalencia jocosa es el rasgo más característico de este tipo de literatura, y parte esencial del realismo grotesco con que se tinta el mundo en ciertos momentos carnavalescos en que hay que arrojarlo todo al retrete, para comenzar de nuevo. No es extrańo que, aunque muchas de estas canciones parezcan meros insultos, las pullas encierren en sí una arcaica concepción según la cual de la lucha de los opuestos pero complementarios ha de nacer lo nuevo, siendo lo obsceno y lo escatológico un recurso verbal que pone de relieve esa paradoja, según han demostrado antropólogos como Victor Turner ${ }^{148}$ en culturas muy alejadas. Por eso podemos encontrar contextos festivos -como los que hemos presenciado en las candelas de La Puebla de los Infantes (Sevilla) - en que hombres y mujeres alternan injurias de versos excrementicios y degradaciones obscenas, con halagos hiperbólicos de esa misma carnalidad. Pareciera que en esos momentos liminares, previos al esplendor primaveral, se quisiera resaltar la turbulenta pugna de contrarios y complementarios mediante la doble y paradójica faz de lo carnal.

Naturalmente, el culo encierra diferentes significados para el hombre y para la mujer, de tal manera que los primeros exaltan el erotismo de las féminas mientras degradan lo que sale de esos mismos culos; por el contrario, el mozo exagera hiperbólicamente el placer de la evacuación, mientras desecha que nada entre a través del orificio, en el fondo receptáculo de lo femenino y terrenal. La gracia radica en la ambivalencia con que en unos casos y otros se juega a 
ponerlo todo patas arriba. Pero además, el realismo grotesco no solo mezcla lo ínfimo y lo sublime, el amor y la sumisión, la sensualidad y la suciedad, sino que busca explícitamente exagerar lo bajo, viejo y podrido. Lo hace deformándolo cómicamente, por lo que no se trata de una crítica moralista -como hace la Iglesia con la censura del pecado o el Estado con la prohibición del desordenni tampoco lo contrario en exclusividad: una apología de los bajos instintos. Más bien, la literatura obscena-escatológica libera amortajando, hace revivir un mundo igualitario, utópico y renovado precisamente mediante la muerte de lo viejo y caduco, lo grosero, pestilente y sucio, sin olvidar que esa es solo una faz de la realidad, detrás de la cual se esconde el placer, la comida, el sexo, y la vida, pues en el fondo no somos sino animales, pese a la cultura que se empeña en ocultar la cara fétida de nuestra naturaleza. 